\title{
Critical Discourse Analysis on The 2019 Presidential Election Discourse Spread on Facebook
}

\author{
Reka Yuda Mahardika ${ }^{1}$, Syihabuddin ${ }^{2}$, Dadang Anshori ${ }^{3}$, Vismaia S. Damaianti ${ }^{4}$ \\ School of Postgraduated, Indonesian Education University, Bandung \\ ${ }^{1}$ rekayudamahardika@upi.edu
}

\begin{abstract}
This research was written based on the hot atmosphere of the 2019 Presidential Election which has triggered the emergence of pros and cons discourses toward each pair of candidates for president and vice president. These discourses were written in a language that does not follow journalistic ethical standards, therefore, it is assumed to be vulnerable to triggering conflict. The purpose of this study was to explain the profile of some news articles about the 2019 presidential election on Situasinews.com and Seword.com from September 23, 2018 until 25 April 2019 which could trigger conflict; explain the representation of some news related to the presidential election in Situasinews.com and Seword.com from September 23 until April 25. This research used qualitative approach by using Van Dijk critical discourse analysis method. This research found that the writings related to the presidential election spreadon Facebook that was connected to Situasinews.com and Seword.com websites did not meet journalistic ethics and those writings usedsarcasm and tendentious languages that it can trigger conflicts between presidential supporters.

Keywords: 2019 presidential election, critical discourse analysis, Situasinews.com, Seword.com
\end{abstract}

\section{A. INTRODUCTION}

Indonesian direct presidential election began in 2004. The elected president was Susilo Bambang Yudhoyono (SBY). SBY served two periods starting from 2004 to 2014. SBY's presidential journey was considered quite democratic by many observers. During the ten years that SBY ruled, Indonesia was seen as good country in the sight of the world. President Barack Obama even praised SBY's ability to manage Indonesia to become the largest democratic country in the world [1].

The new era of direct presidential elections began again in 2014. Jokowi and Prabowo were promoted as presidential candidates in that year. The elected president was Jokowi who later managed to become president for two periods. Analysts say that the election in this era is the most brutal presidential election in the history of Indonesian elections. Many factors become the parameters. One of them is discourses spread on social media that contain hate speech. The discourseswere made to undermine the credibility of the presidential candidate pairs [2].

Social media has become one of the media considered to have a responsibility in spreading the discourses that they become viral. Especially, this situation is supported by the fact that Indonesia 
is a country with the third largest user of social media in the world. Consequently, discords and conflicts began to occur in the virtual and real world.

In critical discourse analysis (CDA), the theory stated that there will always be certain interests and ideologies in a discourse. Fairclough stated that the news in media always coverage ideology for certain interests [3].

Based on the background mentioned above, this research is interesting to be conducted because it will be useful to increase the variety ofCDA research, especially the study of discourse related to the election. This research can also be considered as a multi-disciplinary study since it examines typography of discourses that are deemed not to meet journalistic ethical principles that it candisrupt the public sphere. This research can be useful for the mass media as a model, therefore, it is expected to be able to create news proportionally by paying attention to the ethical principles of journalism.

The purpose of this research is to explain the profile of some news articles related to the 2019 presidential election in Situasinews.com and Seword.com from September 23, 2018 until 25 April 2019 which could trigger conflict; explain the representation of some news related to the presidential election in Situasinews.com and Seword.com from September 23 until April 25.

The research on critical discourse analysis (CDA) has been conducted by some researchers in advance. Suciartini researchedMata Najwa program on Metro TV with the theme "Semua karena Ahok". The results of his research show that (1) the macro structures found in this research are Ahok's policies and leadership and the reclamation of G Island; (2) the superstructure found is the introduction, discussion and conclusions which contain criticisms toward Ahok's leadership style; and (3) from the micro structure, there are semantic, syntactic, and stylistic analyzes, namely strict, straightforward, and transparent language [4]. Other research was conducted by Mustafaentitled "Language and Ideology in Texts on Globalization: A Critical DiscourseAnalysis". The paper discusses how discourse and ideology are interconnected in texts on globalization, especially the global economy. As a result of the textual and sociological analysis, the paper identifies two central interrelated ideologies in the discourse of globalization: new capitalism and neoliberalism.[5].Rustandi conducted a CDA research entitled "Pencitraan Politik Daring: Strategi Memenangkan Massa Digital Menjelang Pemilu 2014". The research explains that candidates who will run to the presidential candidacy conducted political branding through online media: fanpage, twitter, blogs, and mainstream online media publications [6]. Poorebrahim (2013) conducted critical discourse analysison how Islam is represented in the western world discourse through the formation of the relations between language and ideology. The result of the analysis shows that Islam is depicted stereotypically and Muslims are depicted negatively and prone to social deviations [7].Further researches were conducted by Aminuddin (2017) entitled "Instagram: Bingkai Kasus Agama di Media Sosial" [8] and Mayasari (2017) entitled "Konstruksi Media Terhadap Berita Kasus Penistaan Agama Oleh Basuki Tjahaya Purnama (Ahok)" [9].

\section{B. METHOD}

The method used in this research is a qualitative method by usingVan Dijk'sCDA approach. Research data are in the form of discourse related to presidential elections starting from September 23, 2018 until April 25, 2019 which can trigger conflicts that are spread on Facebook (FB). Those discourses, after being traced, come from various site sources. This research focuses only on 
discourses from two sites, namely situasinews.com as an opposition site that is countergovernment (Group 02 [pro-Prabowo]) entitled Jadi Penjilat Jokowi, Bebas dari Jerat Hukum. Another site, namely seaword.com as a pro-government site (Group 01 [pro-Jokowi]) entitled Mari Rayakan Kemenangan, Menertawakan Pecundang Ngeyel.

\section{RESULT AND DISCUSSIONS}

\section{Critical Discourse Analysis based on Micro Structure}

Thematic elements are often known asmain ideas, summaries, or topics of a text. Topics are understood to figure out the global meaning of a text. Theme is the formulation and crystallization of topics that will become the basis of the talks or discussions. For example in newspapers, big themes are usually put on the front or first page. The theme can then be divided into small topics [10].

In the discourse ofMari Rayakan Kemenangan, Menertawakan Pecundang Ngeyel there is a theme entitled Kemenangan yang Gemilang from Group 01. The theme is crystallized from topics that tell a variety of claims of victory stated by Group 02 . The claims of victory were stated by Group 02 starting from the campaign period, quick count, appointment of Election Commission (KPU), untilfiling claims to the Constitutional Court (MK). On the other hand, Group 01 is described in the discourse as the ones whodo not respond to all these claims. Group 01 is described to be a patient party that absolutely won the election because the claimsof Group 02 were rejected by the Court.

In the discourse entitled Jadi Penjilat Jokowi, Bebas dari Jerat Hukum, there is a theme Kebal Hukum Bagi Kubu 01. The theme is crystallized from the facts of the supporters' names of Group 01 that were reported to law due to hoax cases are still not processed. On the other hand, hoax spreaders of Group 02 were arrested and prosecuted.

\section{Critical Discourse Analysis based on Super Structure}

\section{- Analysis of Seword.Com}

Schema can be interpreted as a systematic plot. The plot arranged from beginning to end until it becomes a united plot. A discourse has opening introduction, content, closing, and conclusion. The structure of the discourse text is divided into at least three parts: opening, content, and closing [11] [12]. Here is how the discourse of Mari Rayakan Kemenangan, Menertawakan Pecundang Ngeyel isstructured and arranged.

The discourse was opened by an introductory sentence meaning that the group of Prabowo had conducted many claims and analysis regarding their victory. Claims and analysisstated by the group of Prabowo were considered provocative/hot. Sebelum hari pencoblosan, kita mendengar banyak analisa. Tak jarang telinga kita dibuat panas oleh klaim dan provokasi kubu Prabowo.

The facts of the group of Prabowo's claim of victory were then presented in sequence. From the discourse which is structured into 17 paragraphs, 14 of them contain of the facts of Prabowo's victory claim. The last three paragraphs are closings and conclusions that contain of a rebuttal to the claim.

After the content scheme was written with a series of claims of Prabowo's victory, the discourse was closed with a text containing the writer's satisfaction because Prabowo's claims of victory were not proven true. The writer's satisfaction was stated in the editorial sentence and the provocative diction, for example, in the diction of the ledekin which has a negative connotation since it means a mockery. In addition, there is also a sentencemari tertawa sepuas-puasnya atas 
kemenangan dan merayakan kekalahan Prabowo, which means the satisfaction on the victory of Jokowi's group that rarely claims victory and satisfaction over the defeat of Prabowo's group which is considered to always claim victory.

The conclusion scheme contains the meaning that the defeat of Prabowo's group occurred because Prabowo was considered a dead card, proven by the sentencekarena Prabowo adalah kartu mati. The dead card (kartu mati) in the sentence means that the biggest mistake is in the figure of Prabowo. Whoever the companion is, Prabowo will always lose. His mistake was due to his inability in everything and his past mistakes.

\section{- Analysis of Situation.Com}

In the discourse titled Jadi Penjilat Jokowi, Bebas dari Jerat Hukum, the discourse was opened with a statement seseorang yang ingin bebas dari jerat hukum walaupun menyebarkan hoaks dan fitnah bisa menjadi penjilat Joko Widodo (Jokowi). That sentence means that someone will be above the law, even though he/she spreads hoaxes and slanders, on the condition that he/she becomes a penjilat(supporter) of Group 01.

The sentence of the statement in the introduction is then phlegmatically explained by the findings of supporters of Group 01 who allegedly spread hoaxes, slander, and even threats of murder, but they were not processed by law. The finding was found in sentences ...beberapa pendukung Jokowi sudah dilaporkan kasus hoaks bahkan ancaman pembunuhan namun tidak ada proses hukum.

The findings in the sentence mentioned above are then explained explicitly with a closing sentence ...publik hanya minta keadilan. Kalau bersalah harus dihukum baik pendukung Jokowi dan oposisi. The closing sentence emphasized that the public felt there was injustice in law enforcement during the election. If this sentence islinked to the previous sentence, a common thread can be drawn, that the injustice is indicated by the absence of legal proceedings towards supporters of Group 01, although they are suspected of spreading hoaxes, slander, and even threats of murder.

After the introductory sentence, the contents, and closing werestated, the discourse is concluded with a statement of hope. The hope was about upholding law justice in order for the countryto be composed. This situation can be understood because this discourse was made in a chaos condition due to the polarization in the social and political sphere in society. The sentence of hope is seen in the sentence, kalau ingin negara tidak gaduh penegakan hukum harus adil.

\section{Critical Discourse Analysis based on Micro Structure \\ - Semantic Analysis}

In semantic analysis, the meaning will emerge when settings, details, intentions, presuppositions, and nominalization are constructed in a sentence. The discourse entitled Mari Rayakan Kemenangan, Menertawakan Pecundang Ngeyel can be understood by presuppositions, namely celebrating the victory of Group 01 and pouting the defeat of Group 02 . The victory was poured with negative connotation diction, loser, meaning the one who losing. In journalistic ethics, the use of sarcasm diction likepecundang(losers) is not justified because it means a negative connotation (sarcasm). Moreover, the diction is constructed with another diction to bemenertawakan pecundang ngeyel, which means laughing at the defeat of a stubborn person (ngeyel).

Diction of sarcasm was also found in the discourse titled Jadi Penjilat Jokowi, Bebas dari Jerat Hukum. The diction of sarcasm found is penjilat (sycophant). Semantically penjilat means 
negative connotation, namely orang yang suka berbuat sesuatu untuk mencari muka (pujian),(people who do something to get praised)

\section{- Syntactic Analysis}

In syntactic analysis, the subject of study is coherence, sentence form, and pronouns. In the sentence sebelum hari pencoblosan, kita mendengar banyak analisa. Tak jarang telinga kita dibuat panas oleh klaim dan provokasi kubu Prabowo. The use of pronoun "kita" (we) consistently indicates that the writer considers the reader to have the same perspective as $\mathrm{him} /$ herself, that is the group of the Jokowi is often made hot/anger by the group of Prabowo's provocation. The use of pronoun "kita" (we) is either asserted repeatedly through active sentences ...kita mendengar banyak analisa or passive sentences, ...tak jarang telinga kita dibuat panas. The affirmation of kita (we) diction shows that the reader is invited to understand the discourse through their perspectives and they (we) become the main characters highlighted in the discourse.

In the discourse titled Jadi Penjilat Jokowi, Bebas dari Jerat Hukum, the diction used by the writer is rakyat (people) andpublik (public). The author represents him/herself as rakyat (the people)who is in opposition to the government. By using the diction of rakyat (people), the writer seems to position him/herself as the people in general who also corrects the government

\section{- Stylistic Analysis}

Stylistic focuses on the study of the style of language used to express intentions. In the article titled Mari Rayakan Kemenangan, Menertawakan Pecundang Ngeyel, a tendentious style of language was found in each paragraph. This represents the writer's total supportstowardsGroup 01. The total supports can be seen from the sentence ...kita di pihak pendukung Jokowi belum merayakan apa-apa.

Other tendentious sentences do not only appear in sentences that contain supports, but also in offensestowardsthe Group 02, as in the sentence tapi nampaknya Prabowo masih belum legowo. Besides, there were also other offensive sentences as shown in the sentence ...merayakan kekalahan Prabowo untuk yang kesekian kalinya.

In this stylistic analysis, it can be found that the article titled Mari Rayakan Kemenangan, Menertawakan Pecundang Ngeyelcontains tendentious discourse towards the Group 01. The alignments are expressly expressed in each paragraph. The alignments appear in sentences that support Group 01 and bringGroup 02 down.

In the discourse titled Jadi Penjilat Jokowi, Bebas dari Jerat Hukum, there is no tendentious sentence found towards group 02 . However, this discourse contains offensive texttowardsGroup 01 , especially in the injustice of law enforcement.

\section{- Rhetorical Analysis}

Rhetorical analysis explains how and in what ways the emphasis of discourse is carried out. In an article entitled Mari Rayakan Kemenangan, Menertawakan Pecundang Ngeyel, an analogy of diction was found similar to kura-kura (tutles) which was anaphorically addressed to Group 02. Turtles here can be interpreted that Group 02 is analogous to a slow figure. Slow figure here means slow to act, think, and slow to admit and understandthe defeat. By being slow, the speech of Group 02 seemed to contain preparations for the 2024 presidential election. The interpretation was taken from the following data.

Besides analogous to turtles, Group 02 is also analogous to howling animals. These analogies certainly do not meet ethics and are sarcastic. It is feared that discourse that does not meet ethics and sarcasm can divide the public sphere. 
In the discourse titled Jadi Penjilat Jokowi, Bebas dari Jerat Hukum, not found many metaphorical diction which is connotative. Discourse is represented in a denotative, direct, and assertive form. However, there is one diction that can be considered a metaphor, namely penjilat (sycophants). In this diction, penjilat (sycophants) does not mean a person who sticks out his tongue to taste. Penjilat (Lickers) in this context are people who are opportunistic.

\section{DISCUSSION}

Research about critical discourse analysis related to general elections has been carried out, for example, research on the dynamics of political communication in Indonesia in the 2014 election [13], research on the language style (rhetoric) of King Jordan when speaking in the international region [14], research on how language is spoken McCain's and Obama related the Iraq war [15],research about how is Islam portrayed in western media [16], research about analysis of selected Iranian and Saudi Arabian print media on civil war in Syria [17]and others. However, research on tendentious discourses that can divide people's social lives, discourses that use the language of sarcasm, has never been done. Because of its authentic nature, this research can be used as a basis for identifying typographic discourses that do not use journalistic ethical codes [18].

\section{CONCLUSIONS}

Macro structure contained in the discourse titled Mari Rayakan Kemenangan, Menertawakan Pecundang Ngeyel there is a theme kemenangan yang gemilang from the Paslon 01 group.The theme is built from topics and content schemes about the Group 02 victory claim series. In micro structure analysis, semantically found sarcasm diction. In a stylistic analysis, the discourse is written tendentiously containing support for Group 01. In the discourse titled Jadi Penjilat Jokowi, Bebas dari Jerat Hukum there is a theme of impunity for Group 01. The theme is built from the fact the names of supporters of Group 01 are reported to the realm of law in the case of hoaks, but still not processed. The discourse is then concluded with a sentence of hope about the enforcement of legal justice. Based on the results of the analysis, it can be concluded that the discourse that is the object of research is tendentious and written without fulfilling journalistic ethical principles.

\section{REFERENCES}

[1]. Virdhani, Mariska H. (2014). "Demokrasi di Era SBY Patut Diapresiasi". Sindonews.[Online].Tersedia:https://nasional.sindonews.com/read/913051/12/demokrasidi-era-sby-patut-diapresiasi-1413720237. (1 Oktober 2019).

[2]. Akuntono, Indra. (2014). "Pemilu ini Paling Brutal". Kompas.com [Online]. Tersedia:https://nasional.kompas.com/read/2014/04/21/1839452/.Pemilu.Ini.Paling.Brutal .(1 Oktober 2019).

[3]. Ahmadi F, Yusep \& Mahardika, R. Y. (2019). Representasi Aksi 212 Di Koran Sindo Dan Media Indonesia (Representation. 15(1), 13-26. https://doi.org/10.26499/jk.v15i1.728

[4] Suciartini, N. N. A. (2017). Analisis Wacana Kritis "Semua Karena Ahok" Program Mata Najwa Metro Tv. Aksara, 29(2), 267. https://doi.org/10.29255/aksara.v29i2.54.267-282

[5] Ar, M., Studi, P., \& Inggris, B. (2015). Language and Ideology in Texts on Globalization: A Critical Discourse Analysis. 5(2), 63-78. https://doi.org/10.5539/ijel.v5n2p63 
[6] Rustandi, D. (2013). Dinamika Komunikasi Politik Menjelang Pemilu 2014. Observasi, 12. https://doi.org/10.1021/es900956c

[7] Poorebrahim, F. (2013). How is Islam Portrayed in Western Media? A Critical Discourse Analysis Perspective. (2007).

[8] Aminuddin, A. T. (2017). Instagram: Bingkai Kasus Agama Di Media Sosial. 9(November 2016), 163-175.

[9] Darmayanti, N., \& Riyanto, S. (1989). Analisis Wacana Kritis Pemberitaan “ Saweran untuk Gedung KPK ” di Harian Umum Media Indonesia. 1-11.

[10]. Mulyana. (2005). Kajian Wacana: Teori, Metode, dan Aplikasi Prinsip-Prinsip Analisis Wacana. Yogyakarta: Tiara Wacana.

[11]. Darmayanti, N., dkk. (2011). "Pidato Politik Susilo Bambang Yudhoyono sebagai Calon Presiden Republik Indonesia 2009-2014: Analisis wacana”. Metalingua Jurnal PenelitianBahasa, Vol. 9 (1), 73-88.

[12]. Ahmadi F., Y. (2014). “Analisis Wacana Kritis: Ideologi Hizbut Tahrir Indonesia dalam Wacana Kenaikan Harga BBM 2013 di buletin Al-Islam yang berjudul 'Menaikkan hargaBBM: Menaikkan angka kemiskinan“.Metalingua Jurnal PenelitianBahasa, Vol. 12 (2), 253-268.

[13] Al-Momani, H. A. (2017). Political Discourse of Jordan: A Critical Discourse Analysis. International Journal of English Linguistics, $7(2), \quad 90$. https://doi.org/10.5539/ijel.v7n2p90

[14] Hariyanto, B. (2016). Analisis Wacana Portal Berita Pemilu Presiden 2014 (Studi pada 10 Portal Berita Terpopuler Tahun 2013). 17(1).

[15] Mccain, J. (2009). Language as a Puppet of Politics: A Study of McCain's and Obama's Speech on Iraq War, a CDA Approach. International Journal of Criminology and Sociological Theory, 2(1), 218-229.

[16] Mirzaee, M. (2015). A Critical Discourse Analysis of Selected Iranian and Saudi Arabian Print Media on Civil War in Syria. 3(11), 67-78.

[17] Poorebrahim, F. (2013). How is Islam Portrayed in Western Media? A Critical Discourse Analysis Perspective. (2007).

[18] K. Saddhono, A. Hasibuan, and M. I. Bakhtiar, "Facebook as A Learning Media in TISOL (Teaching Indonesian to Speakers of Other Languages) Learning to Support The Independency of Foreign Students in Indonesia," in Journal of Physics: Conference Series, 2019, vol. 1254, no. 1, p. 12061. 